\title{
RAILROADS AND LUMBER MARKETING 1858-78: THE RELATIONSHIP BETWEEN AN IOWA SAWMILL FIRM AND THE CHICAGO \& NORTHWESTERN RAILROAD
}

\author{
By George W. Sieber \\ Wisconsin State University, Oshkosh
}

Settlers moved west in the second half of the 19th century, built new farms, cities, and created an extensive market for lumber. Northern sawmill men from Chicago to Oshkosh competed for the western trade with producers along the Mississippi River from Minneapolis to St. Louis. This case study of the transportation problems of one of the largest downriver sawmill firms, W. J. Young \& Company, reveals the role of railroads in determining who would win the western markets. While railroad rates have been discussed in writings on economic competition, historians usually neglect to portray the importance of freight weights (the weight that roads allowed shippers to place in each car). This article illuminates the importance of this factor to entrepreneurs in the lumber business.

W. J. Young entered the lumber business at Clinton, Iowa, in 1858. Located due west of Chicago, Clinton became the heart of the middle Mississippi River lumber district. Towns immediately to the north and south threatened her commercial supremacy, but Clinton benefited from becoming a site of the Chicago, Iowa, and Nebraska Railroad. ${ }^{1}$ By 1869 there were five lumber companies in Clinton, the leading producer being W. J. Young \& Company. In 1869 the firm produced $29,000,000$ feet of lumber, $12,000,000$ shingles, and $6,000,000$ lath. ${ }^{2}$ Sales amounted to $\$ 541,332.84$. The cost of logs, labor, 1872 .

${ }^{1}$ Clinton Age, Dec. 23, 1870; July 7, Dec. 29, 1871; March 29, ${ }^{2}$ Ibid., Feb. 11, 1870. 
and other expenses, $\$ 461,627.41$, subtracted from sales, left Young $\$ 79,705.43$ to account for in terms of proprietary interest. $^{3}$ A small business, dealing in an area where concentration was trivial, W. J. Young \& Company's capital originated among entrepreneurs in Cincinnati, Ohio. An Irish immigrant, and something of an Horatio Alger type figure, Young managed the firm by himself and eventually bought the interests of his partners.

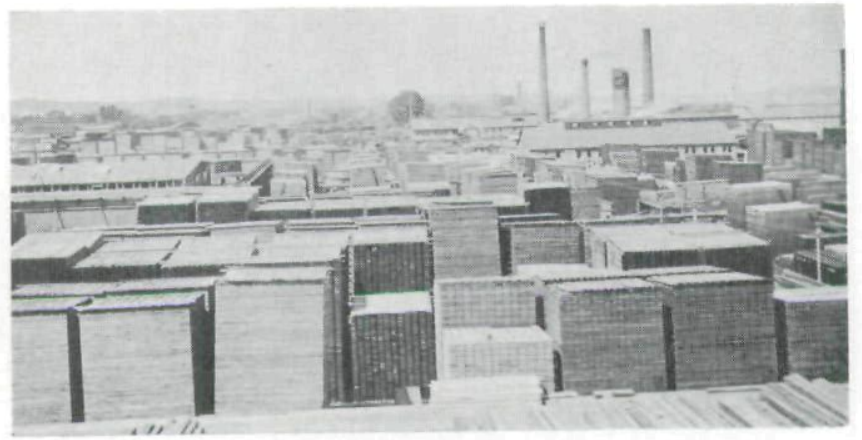

W. J. Young Sawmill, Clinton; it was one of the largest of its kind in the early 1900s.

From the beginning of his business, Young found that his marketing outlets depended mostly on the railroad. Teams of horses hauled retail orders from his yard, but his wholesale business was with dealers along the railway westward from Clinton. The Chicago, Iowa \& Nebraska Railroad leased the Galena \& Chicago Union Railway and became the Chicago \& North Western (C\&NW). The line reached Council Bluffs on the Missouri River in 1867. By 1870, Clinton lumber firms had yards at various points along the line which connected with the Union Pacific and other roads at Omaha. ${ }^{4}$

Preferring to sell to independent dealers, Young did not establish any branch yards under his own name until 1868, when he started one under the management of L. B. Wadleigh who had assisted in the office at Clinton. Bypassing all of the towns of interior Iowa, Young stationed Wadleigh at Council

${ }^{3}$ Ibid.

${ }^{4}$ Ibid., Dec. 23, 1870; July 7, 1871. 
Bluffs on the Missouri River. Why did he do this? He claimed later that he did it at the "solicitation" of officers Gault and Dunlap of the C\&NW Railway. He also maintained that they promised to protect his business at the Missouri River by allowing him favorable freight rates. ${ }^{5}$

Other than preserving good relations with the railroad, which profited from the freight, Young mentioned only two benefits that he expected to obtain from the new yard. One was that he could pile much of his lumber outside of Clinton and cut the risk of total loss by fire. ${ }^{6}$ The second advantage was that regardless of whether or not he had orders from dealers, he could ship large quantities of lumber from Clinton whenever railroad cars were available. This was important because there was often a serious shortage of cars. Although Young claimed that the risk of fire was tremendous, railroads did not consider forest products to be perishable goods like field or orchard crops. Railroad officials knew that lumber was "sure traffic" which they could move when they were ready. Therefore lumber companies often found that they could not distribute their product promptly at seasons of the year when railroads transported grain. ${ }^{7}$ During three months in 1868, Young claimed that he lost $\$ 80,000$ in sales because of a shortage of cars. ${ }^{8}$ He would not solve his problem by having a branch yard, but that was one place he could stock ahead of car shortages.

${ }^{5} \mathrm{~W}$. J. Young to the following officials of the C. \& N. W. Ry., Chicago: M. M. Kirkman, Dec. 19, 1873, LPB 33, p. 412; C. C. Wheeler, Feb. 16, 1872, LPB 31, p. 214; C. G. Eddy, July 27, 1878, LPB 55, p. 138; Apr. 30, 1878, LPB 54, p. 561. Note: All of the manuscript sources are from the W. J. Young \& Co. special collection at the University of Iowa. Young wrote all of the correspondence here cited at Clinton, Iowa. The notes designate the particular record, letter press book, or box where information is found. In the notes, LPB means letter press book, and C. \& N.W. Ry, means Chicago \& Northwestern Railway.

${ }^{6}$ W. J. Young to G. C. Hixon, LaCrosse, Wis., July 25, 1868, General Letter Book, p. 743.

${ }^{7}$ Ovid M. Butler, The Distribution of Softwood Lumber in the Middle West: Wholesale Distribution, Studies of the Lumber Industry Part VIII (U. S. Dept. of Agriculture: Office of the Secretary, Report No. 115, Washington: Government Printing Office, 1917), p. 46.

${ }^{8}$ W. J. Young to G. P. Lee, C. \& N. W. Ry., Chicago, Ill., No. 12, 1868, LPB 15, p. 870. To Hersey, Staples \& Bean, Stillwater, Minn., Nov. 12, 1868, LPB 15, p. 881. 
Young hoped that his branch yard would control the wholesale and retail trade at Council Bluffs. But retailers would not buy from him unless he could keep his prices as low as those producers located at Chicago, Oshkosh, Wis., or in the Mississippi markets of Davenport, Rock Island, Muscatine, Burlington, and Hannibal, which had railroad connections with Council Bluffs. Minneapolis and St. Paul lumber men were potential competitors awaiting railroad development.

The Chicago, Burlington \& Quincy reached Council Bluffs in 1869 , carrying $117,453,000$ feet of lumber westward from Chicago the same year, while the C\&NW carried 99,508,000 feet. ${ }^{9}$ Chicago was the largest lumber market in the world, and her dealers quickly took advantage of circumstances which occasionally prevented logs or lumber from being rafted to the downriver mills and yards on the Mississippi. For example, Young could not obtain an adequate supply of logs in the summer and fall of 1863 because of exceptionally low water; but Chicago, competing at Clinton prices, was daily sending 50,000 to 60,000 feet of lumber west of Clinton on the C\&NW Railway. ${ }^{10}$ In desperation, Young decided to do as some of his fellow millmen did, and purchased lumber in Chicago himself. In so doing he accomodated his customers, and retained their trade, but his profits were small. ${ }^{11}$

Young claimed in July, 1867, that over half of the lumber going west came from the glutted Chicago market. He hoped for the best, but thought that the Mississippi River producers "would have to keep in the background until the Michigan \& Wisconsin pineries tributary to Chicago are exhausted." ${ }^{2}$ The

${ }^{9}$ Agnes M. Larson, History of the White Pine Industry in Minnesota (Minneapolis: University of Minnesota Press, 1949), pp. 105, 122.

${ }^{10}$ Frederick Merk, Economic History of Wisconsin During the Civil War Decade (Madison: State Historical Society of Wisconsin, 1916), p. 81. W. J. Young to Branch Crooks \& Co., St. Louis, Mo., Jnly 9, 1863, LPB 4, p. 414. To David Cover, Stillwater, Minn., July 29, 1863, LPB 4 , p. 466.

${ }^{11} \mathrm{~W}$. J. Young to E. H. Brower, Chicago, Ill., Aug. 8, 1863, LPB 4, p. 495. To John C. Gault, Chicago, Ill., Aug. 8, 1863, LPB 4, p. 496. To David Stoner, Toledo, Ia., Aug. 15, 1863, LPB 4, p. 506.

${ }^{12}$ W. J. Young to Samuel F. Hersey, Bangor Maine, July 16, 1867, LPB 12, p. 437. 
Clinton lumber man repeated his analysis in 1869, saying that the Chicago wholesalers governed those of the Mississippi River. Their salesmen along the Iowa railroad lines solicited orders at prices much lower than Young could profitably meet. The contest, he said, was between "the Mississippi \& the Lakes." If the lumber men on the river allowed the lake men to take the trade one season, the precedent might become a habit. ${ }^{13}$

The C\&NW Railway helped determine that the windy city's dealers should share the western market. When Chicago's dealers obtained railway connections to the Mississippi and beyond, they were often able to undersell those located on the river because of a favorable rate structure. ${ }^{14}$ Young charged in 1869 that all of the railroads that ran west from the Mississippi were companies "whoes [sic] great interest is in Ill. [Illinois] Consequently they transport lumber from Chicago to points on the Iowa R. Rds [sic] at almost the same rates they do from the river." ${ }^{15}$ One of the main reasons for low rates on lumber from Chicago was that the railroads shipped grain eastward to the metropolis and needed a product to fill the cars on their westward runs. Rather than haul empty cars, they gave low rates to lumber shippers. ${ }^{16}$

Railroad freight agents were vital figures in the struggle among competing lumber interests. Manufacturing districts competed with each other for better rates, and individual firms sought secret concessions. In 1866 Young believed that freight rates were too high for the best interests of Clinton, but he opposed any action on the part of lumbermen to seek redress from the railroads. He thought that such activity could achieve nothing but ill will. Moreover, he disliked any action that might tend to keep "Eastern \& Foreign capital" out of Iowa railroad projects. ${ }^{17}$ There was also the fact that

${ }^{13}$ W. J. Young to Hersey, Staples \& Bean, Stillwater, Minn., July 8, 1869, LPB 18, p. 425.

${ }^{14}$ Robert F. Fries, Empire in Pine: The Story of Lumbering in Wisconsin 1830-1900 (Madison: State Historical Society of Wisconsin, $1951)$, pp. 82-83.

${ }^{15}$ W. J. Young to L. C. Stanley, Chippewa Falls, Wis., Feb. 12, 1869, LPB 16, p. 493.

${ }^{16}$ Fries, Empire in Pine, p. 93. 
railroads used large amounts of lumber and construction timbers. Not only was the C\&NW one of Young's best customers, but he counted on the promise of the railway to give him rates as low as those of any roads carrying lumber from points other than Clinton. ${ }^{18}$

Young instructed Wadleigh, who operated the branch yard at Council Bluffs, to find out the lowest rates of other lines such as the Chicago, Rock Island \& Pacific. Then the Clinton lumber man used the information to make his case for protection to the $\mathrm{C} \& \mathrm{NW}$. The railroad charged regular rates to all outward appearances, but arranged for "drawbacks" or rebates through the offices. ${ }^{19}$ Retailers often allowed sawmill operators to arrange terms on shipments, and demanded delivered prices because they knew that the mill men, being big operators and shippers, could obtain concessions from railroads that the small dealers could not. Nevertheless, dealers at Council Bluffs watched each other closely, inspected shipments, and tried to ferret out hidden rates.

In 1870 Young had Wadleigh cross the Missouri River and establish an additional yard in Omaha. Young l a ter claimed that the C\&NW officials had suggested this undertaking as well as the venture at Council Bluffs. ${ }^{20}$ Whether or not the railroad initiated the expansion of Young's business, the Clinton lumber man learned in the 1870's that he needed the services of the railway more than the road needed his lumber. The railroad could buy from numerous firms, but Young depended on the C\&NW to carry his products to Council Bluffs and Omaha. In a position to charge whatever the

${ }^{17}$ W. J. Young to Chambers Bros., Muscatine, Ia., Mar. 26, 1866, LPB 9, p. 512.

${ }^{18}$ W. J. Young to C. C. Wheeler, C. \& N. W. Ry., Chicago, Ill., Feb. 16, 1872, LPB 31, p. 214. To C. G. Eddy, C \& N. W. Ry., Chicago, Ill., July 27, 1878, LPB 55, p. 138. W. F. Battis, Clinton, Ia., to C. G. Eddy, C. \& N. W. Ry., Chicago, Ill., Apr. 30, 1878, LPB 54, p. 561. W. J. Young to L. B. Wadleigh, Council Bluffs, Ia., June 5 and 21, 1869, LPB 18, pp. 24, 287; Aug. 20, 1869, LPB 20, p. 101.

${ }^{19} \mathrm{~W}$. J. Young to L. B. Wadleigh, Council Bluffs, Ia., Aug. 26, 1869, LPB 20, p. 117; Sept. 20, 1870, LPB 20, p. 925.

${ }^{20} \mathrm{~W}$. J. Young to C. C. Wheeler, C. \& N. W. Ry., Chicago, Ill., Feb. 16, 1872, LPB 31, p. 214. To C. G. Eddy, C. \& N. W. Ry., Chicago, IIl., July 27, 1878, LPB 55, p. 138. 
traffic would bear, the railway apparently did so, but it was also interested in protecting shippers on its lines against those who used other roads.

Lumber men continually demanded more favorable freight rates, adequate supplies of cars, and permission to load them heavily without extra charge. W. J. Young \& Company often received secret rates or rebates from the C\&NW but so did other firms, both from that line and other railroads that entered Omaha from different markets. Wadleigh complained in March, 1870, that the Chicago, Rock Island \& Pacific gave an advantage to dealers who shipped from Davenport, Iowa. Moreover, in spite of a recent understanding, the C\&NW, giving reduced rates to Young's competitors on the same line, led Wadleigh to declare: “They talk about fostering our trade. It is all bosh. They are stabing us at every turn . . . [and] furnish our opponents with tools to cut our throats with." ${ }^{21}$

Young's relative standing with the railroad, as compared with other shippers, is difficult to determine. He assured Wadleigh that they were still going to have protection, and during the months between October, 1870, and May, 1871, the road allowed them a rebate of $\$ 10$ on every car that they shipped to the Missouri River. ${ }^{22}$ But Wadleigh complained in May that his rivals, Harris \& Foster, were supplied a new special rate from the C\&NW that put W. J. Young and Company at a disadvantage. ${ }^{23}$

Meantime Wadleigh felt competition from markets on other railroads. Shippers from Davenport and Chicago had special rates. ${ }^{24}$ Moreover, Wadleigh pointed out that local competitors, George Hoagland and Harris \& Foster, bought large quantities of lumber at Minneapolis, and would soon be able to ship over the new St. Paul \& Sioux City Road, and

${ }^{21}$ L. B. Wadleigh, Council Bluffs, Ia., to W. J. Young, Mar. 28, 1870, LPB D, p. 4.

${ }^{22}$ L. B. Wadleigh, Council Bluffs, Ia., to W. J. Young, Apr. 2, 1870, LPB D, p. 32. For rebates see LPB G, pp. 68, 517; LPB F, p. 579; W. J. Young \& Co., Council Bluffs, Ia., to W. J. Young, Apr. 8, 1871, LPB H, p. 38.

${ }^{23}$ L. B. Wadleigh, Council Bluffs, Ia., to W. J. Young, May 10, 1871, LPB K, p. 7; and May 11, LPB H, p. 220. p. 7.

${ }^{24}$ L. B. Wadleigh, n.p., to W. J. Young, May 10, 1871, LPB K, 
the Omaha \& North Western from Omaha to Sioux City. ${ }^{25}$ In February, 1872, Wadleigh was so disgusted with freight rates that he asked Young if they could boat or raft lumber from Clinton to St. Louis and ship it from there. ${ }^{26}$ In March he asked if they could ship lumber from Clinton to Burlington, and over the Chicago, Burlington \& Quincy to the Missouri River. At other times Wadleigh just commented that the railroad tariff was "outrageous." ${ }^{27}$

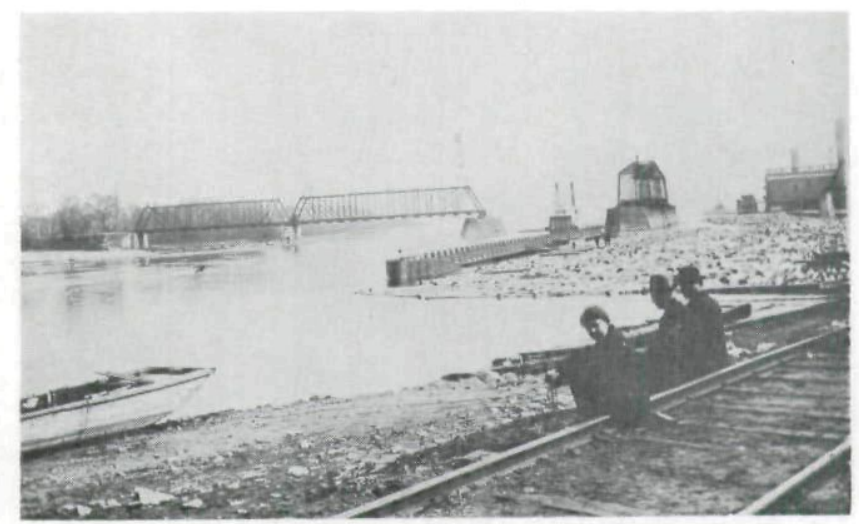

View of the Mississippi River at Clinton, 1890s.

Young believed in March, 1874, that if the Iowa legislature would pass a railroad tariff bill, the law would result in lower rates from Clinton to the Missouri River. ${ }^{28}$ The legislature passed a so-called Granger law that went into effect July 4, providing for a schedule of maximum passenger and freight rates for railroads operating in Iowa. At first the Clinton lumber men were not pleased with the law because the C\&NW abolished the special rates that the mill men had secured to various Iowa locations. The railroads also raised its

${ }^{25}$ L. B. Wadleigh, Council Bluffs, Ia., to W. J. Young, Jan. 15, 1872, LPB J, p. 381. 731.

${ }^{26}$ L. B. Wadleigh, n.p., to W. J. Young, Feb. 23, 1872, LPB K, p.

${ }^{27}$ L. B. Wadleigh, Omaha, Neb., to W. J. Young, Mar. 27, 1872, LPB L, p. 41.

${ }^{28} \mathrm{~J}$. Young to Waterman \& Bernard, St. Joseph, Mo., Mar. 13, 1874, LPB 38, p. 421. 
through rates, however, and this hurt Chicago wholesalers. When the businessmen of the Mississippi River towns realized this, they became enthusiastic supporters of the law. ${ }^{29}$

In 1876 Young and his main Clinton competitor, Chancy Lamb, opposed a movement to repeal the law. Young corresponded with John S. Hancock of the Dubuque Board of Trade and other businessmen of that city to see what they wanted to do about the bill. ${ }^{30}$ Young and Lamb, with three other Clinton businessmen, spent nearly a week in Des Moines advocating that the legislature retain the law. The C\&NW had lobbyists there to work for unconditional repeal, and Young was afraid that they would win by giving out passes. ${ }^{31}$ He made at least two trips to Des Moines to lobby for retaining the law, and sent some memorials to distribute to each member of the legislature. ${ }^{32}$ The upshot was that in 1876 the legislature failed to repeal the traff bill.

The matter was not, however, completely settled. In May the C\&NW, for no apparent reason, began work near the Clinton railway bridge in manner that hindered the passage of logs to one of Young's mills. Convinced that the obstruction was merely retaliation for his opposition to the repeal of the tariff law, Young protested to the railroad that it was not wise to open a fight with such a large shipper-but he admitted that the road had him at a disadvantage. ${ }^{39}$

Whether or not the railroad officials were actually vindictive, Young decided to do nothing to irritate them in the future. In 1878 the railroad again sought repeal of the Granger law. This time Young took no part in the proceedings. He wrote that he thought that the law was a good one, but that

${ }^{29}$ Mildred Thorne, "The Repeal of the Iowa Granger Law, 1878," Iowa Journal of History, 51 (Apr. 1953), pp. 105, 114.

30 W. J. Young to M. H. Moore, Dubuque, Ia., Jan. 8, 1876, LPB 46, p. 34. To John S. Hancock, Dubuque, Ia., Feb. 23, 1876, LPB 46, p. 407.

${ }^{31}$ Ibid. Clinton Age, Feb. 25, 1876

${ }^{32}$ W. J. Young to J. S. Hancock, Dubuque, Ia., Feb. 29, 1876, LPB 46, p. 475. To E. H. Thayer, Des Moines, Ia., Feb. 28, 1876, LPB 46, p. 460 .

${ }^{33}$ W. J. Young to J. S. Oliver, C. \& N. W. Ry., Clinton, Ia., May 5, 1876, LPB 47, p. 143. To C. C. Washburn, La Crosse, Wis., May 12 , 1876, LPB 47, p. 261. 
there was no strength for its defense in Clinton where lumber men had "suffered through a spirit of retaliation" for the past two years. ${ }^{34}$ The legislature soon repealed the law, ${ }^{35}$ and by December the railroad advanced rates to all points. ${ }^{36}$ Nevertheless, rates (cents per 100 pounds between two locations) tended to decline in the second half of the nineteenth century. ${ }^{37}$ Lumbermen did not grumble so much about transportation costs as such, but about their rates as compared to those of competitors. The relative rate was the important thing.

As much as he was interested in railroad rates, Young was even more concerned with the weights that railroads allowed to be shipped in cars without extra charge. Railroad rates were not very meaningful unless the roads weighed the cars and made shippers pay their rates per pound. The C\&NW usually considered 20,000 pounds to be the standard load. A standard car could hold much more than 20,000 pounds of lumber, however, especially if the wood was green. The difference in weight between dry and green lumber was approximately 1,000 pounds per 1,000 feet. $^{38}$

If a railroad desired to favor a shipper, the officials might assume that a car full of lumber weighed 20,000 pounds and charge for that amount whether or not they went through the motions of weighing it. The Chicago, Burlington \& Quincy was apparently the road most accustomed to heavy loading. One dealer described how he received a rate of $\$ 25$ per car when the ordinary rate was $\$ 50$, and stated that the road was "perhaps not very particular about end filling whether [or

${ }^{34}$ W. J. Young to John S. Hancock, Dubuque, Ia., Jan. 25, 1878, LPB 53, p. 815; Feb. 21, 1878, LPB 54, p. 23.

${ }^{35}$ Throne, "Repeal of Iowa Granger Law," pp. 97-130. W. F. Battis, Clinton, Ia., to C. G. Early, C. \& N. W. Ry., Chicago, Ill., Apr. 13, 1878, LPB 54, p. 432.

${ }^{36}$ W. J. Young to T. M. Sinclair, Cedar Rapids, Ia., Dec. 3, 1878, LPB 56, p. 254.

${ }^{37}$ See the table of rates from Clinton to Council Bluffs and Omaha, 1868-1882 (compiled from the Young papers) in Chapter VIII of the author's unpublished doctoral dissertation, "Sawmilling on the Mississippi: the W. J. Young Lumber Company 1858-1900," University of Iowa, 1960 .

${ }^{38}$ W. J. Young to L. B. Wadleigh, Council Bluffs, Ia., Nov. 25, 1868, LPB 16, p. 6. To Parmaleu \& Kershon, Hallmonth, Neb., Mar. 3, 1869, LPB 16, p. 649. 
not] we kept the limit of 24,000 lbs." ${ }^{39}$ The Northwestern Lumberman, a reliable trade journal, described the Chicago, Burlington \& Quincy as a road that cultivated the Chicago lumber trade with great success. The line had a good terminal position in Chicago, and eventually passed through the richest sections of Illinois, Iowa, Kansas, and Nebraska. As the journal explained, ". . . it was understood that a wholesale dealer who stood in with the 'Q' was about sure of success." 40

During most of the time that Young had branch yards at Council Bluffs and Omaha, the C\&NW allowed him to load only 20,000 to 22,000 pounds of lumber per car, which usually amounted to less than 7,000 feet. Young's employees prepared memoranda showing that other shippers obtained heavier loads on competing lines, and sometimes over the C\&NW itself. In May, 1871, for example, Wadleigh listed the following examples of heavy loading from which his rivals benefited:

April 13, Hoagland received a car from Davenport with 9,000 feet of fencing in it; April 19 he received one from Burlington with 10,700 feet of common boards and 20,000 shingles for stuffing. The Chicago, Burlington \& Quincy weighed the car, but billed it at regular charges. April 20, Harris \& Foster received a car from Moline, Illinois with 8,664 feet of green lumber. May 2, over the C\&NW they received a car from either Clinton or Camanche containing 11,800 feet, and Hoagland obtained one from Young's neighbor, Chancy Lamb, with 10,800 feet of flooring and 14,000 shingles. On May $5 \mathrm{Mr}$. Nye told Wadleigh about getting 10,000 to 13,000 feet on the Burlington road, and May 18 another customer asked why W. J. Young \& Company could not put more than 6,000 to 6,500 feet in cars when the Burlington allowed 9,000 to 10,000 . Wadleigh concluded the memorandum by listing six cars that he received, the largest load containing 6,976 feet. ${ }^{41}$

${ }^{39} \mathrm{C}$. P. Deatherage, The Early History of the Lumber Trade of Kansas City (Kansas City: Retail Lumberman, 1924), p. 6.

${ }^{40}$ Northwestern Lumberman, Oct. 11, 1890, p. 2. 50-53.

${ }^{41}$ L. B. Wadleigh, n.p., to W. J. Young, May 19, 1871, LPB K, pp. 
Young requested that the C\&NW "advise the proper person in Clinton in relation to not weighing our CB [Council Bluffs] \& Omaha lumber, or if weighed, to pass it if it overruns the limit of weight." ${ }^{22}$ But in June Wadleigh still complained that shippers from Davenport and Moline were beating them by 2,000 to 4,000 feet per car. ${ }^{43}$

In February, 1872, the railroad refused to haul several of Young's cars because they exceeded the maximum limit of 24,000 pounds. Writing to Wadleigh, Young said, "We see nothing else but that we must give up that trade if not allowed the same privileges our competitors have on other lines." ${ }^{\prime 4}$ He protested to the C\&NW:

\begin{abstract}
... You have us in your power and can crush us. And we may as well make up our minds at once to discontinue our business at C. Bluffs \& Omaha and pocket the loss. . . . if you think it best to crush us after going out to $\mathrm{CB}$ and Omaha at the solicitation of Mr. Gault \& Mr. Dunlap all right. We simply cant [sic] help ourselves. ${ }^{45}$
\end{abstract}

The railroad argued that overloaded cars were liable to break down, damage the road, and possibly cause loss of life. Young invited examination of the record and offered to pay for all damages caused by his cars if other shippers would do the same, but apparently the road did not take this proposition seriously. ${ }^{46}$ The Clinton lumber man had another argument to present to the North Western road. Sometimes he shipped less than the standard load of 20,000 pounds in a car. He maintained, therefore, that to be fair the road should overlook the weight when he ran a little over 20,000 pounds.

${ }^{42}$ W. J. Young to C. C. Wheeler, C. \& N. W. Ry., Chicago, Ill., May 25, 1871, LPB 26, p. 161.

${ }^{43}$ L. B. Wadleigh, Council Bluffs, Ia., to W. J. Young, June 13, 1871, LPB H, p. 361.

${ }^{44}$ W. J. Young to L. B. Wadleigh, Omaha, Neb., Feb. 16, 1872, LPB 28, p. 351.

${ }^{45}$ W. J. Young to C. C. Wheeler, C. \& N. W. Ry., Chicago, Ill., Feb. 16, 1872, LPB 31, p. 214.

${ }^{46}$ W. J. Young to C. C. Wheeler, C. \& N. W. Ry., Chicago, Ill., Feb. 21, 1872, LPB 28, p. 365. 
Young did not own a track scale, and his workers could not always judge the weight accurately. The cost of adjusting the load in a car after the railroad weighed it was prohibitory. On the other hand, the railroad sometimes charged a higher rate for all weight over 20,000 pounds than for the rest of the load, with an absolute limit of 24,000 pounds. Believing that the practice of increasing the rate on excess poundage was extremely unfair, Young wrote to the freight agent in 1875:

We do not ask any deduction made when the load is only 15,000 lbs. yet you do not seem disposed to meet us with any spirit of good feeling or justice. You know you have or at least think you have us in your power and you are bound to use it. ${ }^{47}$

The railroad made one concession. The standard weight became 22,000 pounds, but the road continued to charge a higher rate cn amounts over that up to the 24,000 limit per car. Once the railroad weighed a car, they would not allow the shipper to unload part of it just to evade the extra freight charge on weight over 22,000 pounds. ${ }^{48}$ In 1876 Young fought unsuccessfully to get the normal limit to 24,000 pounds, and in 1877 continued to protest his weight limits as compared to shippers in Chicago and Minneapolis. Young's branch yard agent at Omaha wrote in 1878 that he had no knowledge of other roads carrying freight from Chicago at reduced rates, but that they permitted overloading to the extent of 28,000 and even 30,000 pounds without extra charge. ${ }^{49}$

${ }^{47}$ W. J. Young to C. C. Wheeler, C. \& N. W. Ry., Chicago, Ill., July 15, 1874, LPB 40, p. 426. To J. S. Oliver, C. \& N. W. Ry., Clinton, Ia., Mar. 19, 1875, LPB 42, p. 886. To H. C. Wicker, C. \& N. W. Ry., Chicago, Ill., Apr. 6, 9, and 13, LPB 43, pp. 126, 167, 208. LPB 43, p. 78.

${ }^{48}$ W. J. Young to Lewis Hammer, Council Bluffs, Ia., June 2, 1875,

${ }^{49}$ W. J. Young to C. G. Eddy, C. \& N. W. Ry., Chicago Ill., Mar. 9, 1876, LPB 46, p. 578; June 20, 1876, LPB 47, p. 744. Vigo Badollet, Omaha, Neb., to H. C. Wicker, C. \& N. W. Ry., Chicago, Ill., Aug. 3, 1878, LPB T, p. 273. 
In August, 1878, when the rate from Chicago to Council Bluffs was 26 cents per 100 pounds, W. J. Young \& Company received a new rate of 17 cents. The normal limit per car became 24,000 pounds, and the maximum 26,000. ${ }^{50}$ The railroad continued to charge what the traffic would bear, but no more, and allowed Young to continue his pursuit of the western trade. The Clinton lumber man's correspondence with the railroad over loading weights was as extensive as his letters about rates. In a sense, railroad rates and loading weights were synonymous terms. An advantage in one could easily be offset by a disadvantage in the other. Finally, an advantage or disadvantage with the railroad could determine success or failure for an entrepreneur in lumber marketing.

${ }^{50}$ George W. Forrest, Clinton, Ia., to Vigo Badollet, Omaha, Neb. Aug. 12, 1878, LPB 55, p. 249.

\section{TELEPHONE EXHIBIT ADDED TO MUSEUM}

One of the most exciting exhibits recently added to the State Historical Museum, Des Moines, is a telephone collection which covers the entire history of the telephone, from a replica of the original instrument used by Alexander Graham Bell in 1875 to the modern "touchtone" telephones and a model of Telstar, the satellite used to relay telephone messages.

Bell's first telephone was a crude device which transmitted the human voice, but not in a recognizable manner. After some perfection of his first apparatus, Bell patented his telephone on March 7, 1876, and a few days later the first complete and understandable sentence was transmitted. At this time, the telephone was generally scoffed at as no more than a scientific toy; however, Bell envisioned a great future of usefulness for his invention.

Once the public recognized the use and effectiveness of the telephone, its popularity grew. Two of the early telephones used in Iowa, certainly the first telephones in use in 
Copyright of Annals of Iowa is the property of State of Iowa, by \& through the State Historical Society of Iowa and its content may not be copied or emailed to multiple sites or posted to a listserv without the copyright holder's express written permission. However, users may print, download, or email articles for individual use. 